\title{
PENGGUNAAN KOMPOS SUMBER BAHAN BAKU LOKAL UNTUK MENINGKATKAN KANDUNGAN N, P, DAN K PADA DAUN TANAMAN KOPI ARABIKA DI KECAMATAN TIMANG GAJAH KABUPATEN BENER MERIAH
}

\author{
(Uses of Compost as Lokal Materials Source to Increase N, P, and K Nutrient Content in \\ Gayo Arabica Coffee Leaves Timang Gajah District, Bener Meriah Regency)
}

\author{
Yardani $^{1}$, Zuraida $^{1}$, Hifnalisa ${ }^{1 *}$ \\ ${ }^{1}$ Program Studi Ilmu Tanah, FakultasPertanian, UniversitasSyiah Kuala \\ *Corresponding author:hifnalisa@ unsyiah.ac.id
}

\begin{abstract}
Abstrak: Kopi adalah komoditas utama perekonomian masyarakat di dataran tinggi Gayo. Petani kopi di Kabupaten Bener Meriah telah menerapkan sistem pertanian organik. Petani kopi organik berangapan bahwa sistem pertanian organik adalah sistem pertanian yang tidak memberikan pupuk ke tanaman hal ini karena kurangnya kesadaran dan pengetahuan petani akan pentingnya memberikan pupuk ketanaman sehingga mengakibatkan kesuburan tanaman rendah dan produksi tanaman kopi rendah. Alternatif yang dapat digunakan adalah pemberian kompos yang dapat dibuat dengan memanfaatkan bahan-bahan yang berada disekitar kebun kopi. Bahan kompos yang digunakan dalam penelitian ini berasal dari tumbuhan gulma T. diversifolia, tumbuhan lamtoro, dan limbah kulit biji kopi. Rancangan yang digunakan dalam penelitian ini yaitu Rancangan Acak Kelompok (RAK) non faktorial yang terdiri dari 7 perlakuan dan 3 ulangan, dengan demikian diperoleh 21 satuan percobaan yaitu : tanpa kompos, kompos lamtoro, kompos T.diversifolia, kompos limbah kulit biji kopi, kompos T.diversifolia + lamtoro, kompos T.diversifolia + limbah kulit biji kopi, kompos lamtoro + limbah kulit biji kopi. Parameter yang diamati adalah kandungan hara N, P, dan K. Pemberian pupuk kompos T. diversifolia, kompos lamtoro, kompos limbah kulit biji kopi, kompos T.diversifolia+lamtoro, kompos $T$. diversifolia+limbah kulit biji kopi, kompos lamtoro+limbah kulit biji kopi dengan dosis $12,5 \mathrm{~kg}$ pohon $^{-1}$ dapat meningkatkan kandungan hara nitrogen, posfor dan kalium. Pemberian pupuk kompos T. diversifolia, kompos lamtoro, kompos limbah kulit biji kopi, kompos T.diversifolia+lamtoro, kompos T. diversifolia+limbah kulit biji kopi, kompos lamtoro+limbah kulit biji kopi dapat meningkatkan kandungan fosfor pada tanaman kopi arabika.
\end{abstract}

Kata Kunci: Kompos, Kopi Arabika, Unsur Hara

\begin{abstract}
Coffee is the main economic commodity of the people in the Gayo highlands. Coffee farmers in Bener Meriah Regency have implemented an organic farming system. Organic coffee farmers think that the organic farming system is an agricultural system that does not provide fertilizer to plants, this is due to the lack of awareness and knowledge of farmers about the importance of providing plant fertilizers, resulting in low plant fertility and low coffee production. An alternative that can be used is the provision of compost which can be made by utilizing materials that are around the coffee garden. The compost material used in this study came from the weed plant $T$. diversifolia, lamtoro plant, and coffee bean husk waste. The design used in this study was a non-factorial randomized block design (RAK) consisting of 7 treatments and 3 replications, thus obtained 21 experimental units, namely: without compost, lamtoro compost, T.diversifolia compost, coffee bean shell waste compost, compost T.diversifolia+lamtoro, T.diversifolia compost+coffee bean husk waste, lamtoro compost+coffee bean husk waste. The parameters observed were the nutrient content of $\mathrm{N}, \mathrm{P}$, and $\mathrm{K}$. The application of $T$. diversifolia compost, lamtoro compost, coffee bean husk waste compost, $T$. diversifolia+lamtoro compost, $T$. diversifolia compost+coffee bean husk waste, lamtoro compost+waste coffee bean husk with a dose of $12.5 \mathrm{~kg}$ tree-1 can increase the nutrient content of nitrogen, phosphorus and potassium. The application of $T$. diversifolia compost, lamtoro compost, coffee bean husk waste compost, $T$. diversifolia+lamtoro compost, $T$. diversifolia compost+coffee bean husk waste, lamtoro compost + coffee bean husk waste can increase the phosphorus content of arabica coffee plants.
\end{abstract}

Keywords: Compost, Arabica Coffee, Nutrients 


\section{PENDAHULUAN}

Sumber devisa Indonesia yang berperan penting dalam sektor industri perkebunan adalah tanaman kopi. Dataran tinggi gayo terdiri dari tiga Kabupaten yaitu Bener Meriah, Gayo Lues, dan Aceh Tengah adalah salah satu daerah penghasil kopi terbesar di Indonesia. Kopi telah menjadi komoditas utama perekonomian masyarakat di ketiga Kabupaten tersebut karena sebagian besar penduduk di wilayah dataran tinggi gayo adalah petani kopi. Petani kopi arabika Gayo di Kabupaten Bener Meriah sekitar $70 \%$ telah menerapkan sistem pertanian organik dan memiliki sertifikat organik untuk memenuhipermintaan pasar ekspor. Sertifikasi yang diperoleh menempatkan posisi kopi organik terbaik di mata dunia berasal dari dataran tinggi Gayo (Disbun Provinsi Aceh, 2013).

Pertanian organik merupakan sistem pertanian yang memanfaatkan bahan-bahan alamiah (organik) dan tidak memanfaatkan bahan kimia sintetis. Pertanian organik merupakan sistem manajemen produksi terpadu yang menghindari penggunaan pupuk buatan, pestisida dan hasil rekayasa genetik, menekan pencemaran udara, tanah, dan air. Petani masih berangapan bahwa sistem pertanian organik adalah sistem pertanian yang tidak memberikan pupuk ke tanaman hal ini karena kurangnya kesadaran dan pengetahuan petani akan pentingnya memberikan pupuk ketanaman sehingga mengakibatkan kesuburan tanaman rendah dan produksi tanaman kopi rendah. Kopi arabika sebagian besar di Kabupaten Bener Meriah tumbuh di tanah Andisol.

Andisol adalah tanah yang terdiri dari mineral short range order (alofan, imogolit, ferihidrit) atau aluminium humus terutama dibentuk oleh bahan vulkanik seperti abu vulkanik, batu apung, silinder, lahar, atau bahan piroklastik dengan komponen koloid (Hardjowigeno, 1993). Kandungan Al dan Fe dalam bentuk amorf memiliki kemampuan mengikat $\mathrm{P}$ dan alofan mampu menahan hingga 97,8\% P. Rendahnya ketersediaan hara P pada tanah Andisol dapat menyebabkan tanah tidak mampu memenuhi kebutuhan hara $\mathrm{P}$ dan kebutuhan hara $\mathrm{N}$, $\mathrm{K}$, Ca dan Mg untuk tanaman kopi arabika (Sukarma, 2014). Upaya yang dilakukan salah satunya yaitu memanfaatkan kompos sumber bahan baku lokal.

Penggunaan kompos bahan baku lokal sangat baikdilakukan dalam menyediakan unsur hara bagi tanaman. Pembuatan kompostidak membutuhkan biaya yang besarhal ini karena memanfaatkan bahan-bahan yang tersedia. Bahan-bahan organik lokal yang dapat digunakan salah satunya adalah limbah-limbah hasil pertanian seperti limbah kulit kopi dan tanaman gulma yang berada di sekitar kebun (Falahuddin et al., 2016). Pemanfaatan kompos bahan baku lokal lebih baik dari pada menggunakan bahan baku kompos yang berasal dari daerah lain karena bahan organik dari daerah lain memiliki kandungan hara yang berbeda dari pada bahan organik lokal. Pemanfaatan kompos bahan baku lokal seperti Tithonia diversifolia, lamtoro, dan limbah kulit biji kopi yang banyak tersedia daerah penelitian ini.

\section{METODE PENELITIAN}

Penelitian ini dilakukan di University Farm Stasiun Riset Bener Meriah di Kecamatan Timang Gajah Kabupaten Bener Meriah dan dilanjutkan di Laboratorium Penelitian Tanah dan Tanaman Fakultas Pertanian Universitas Syiah Kuala. Penelitian ini dilakukan pada Juni hingga September 2020.

\section{MATERI DAN METODE}

Penelitian ini menggunakan alat yang digunakan pada penelitian ini yaitu: parang, karung, terpal plastik, cangkul, GPS, garu, amplop sampel, karet gelang, gembor, timbangan 
analitik, oven, grinder, spektrofotometer, AAS (Atomic Absorption Spectrophotometer), alatalat gelas dan alat destilasi. Bahan yang digunakan dalam penelitian ini adalah Effective microorganisme $\left(\mathrm{EM}_{4}\right)$, pangkasan tanaman $T$. diversifolia, pangkasan daun lamtoro, kulit limbah biji kopi, $\mathrm{H}_{3} \mathrm{BO}_{3}, \mathrm{NaOH}, \mathrm{H}_{2} \mathrm{SO}_{4}$, Aquades, dan bahan-bahan lainnya.

\section{METODE PENELITIAN}

Penelitian ini menggunakan Rancangan Acak Kelompok (RAK) non faktorial dengan 3 ulangan dan terdiri dari 7 (tujuh) perlakuan sehingga terdapat 21 unit sampel daun tanaman yang akan diamati. Dosis kompos yang dipakai yaitu $12,5 \mathrm{~kg}^{\text {pohon }}{ }^{-1}$. Perlakuan yang digunakan yaitu: tanpa kompos, kompos lamtoro, kompos T.diversifolia, kompos limbah kulit biji kopi, kompos T.diversifolia+lamtoro, kompos T.diversifolia+limbah kulit biji kopi, kompos lamtoro+limbah kulit biji kopi.Kompos diaplikasikan pada tanaman kopi arabika berumur 8 tahun kemudian dilakukan pengambilan sampel tanaman setelah 3 bulan dari pengaplikasian kompos. Sampel daun dianalisis di laboratorium untuk mendapatkan hasil. Hasil analisis kemudian dilakukan pengujian dengan menggunakan uji BNJ pada taraf $1 \%$ dan 5\% untuk melihat pengaruh kompos pada tanaman kopi arabika.

\section{Prosedur Kerja}

\section{Penentuan Objek Penelitian}

Penentuan objek diawali dengan melakukan survei dilapangan lalu menentukan lokasi penelitian. Luas lokasi penelitian seluas $400 \mathrm{M}^{2}$ dengan jarak tanam 2,5 x 2,5 m pohon ${ }^{-1}$ setelah menentukan lokasi penelitian kemudian dipilih tanaman kopi yang berumur 8 tahun, kemudian ditetapkan 21 sampel tanaman kopi yang berumur seragam dan diberi tanda atau label.

\section{Pengaplikasian Kompos}

Pupuk kompos yang telah jadi atau matang kemudian diaplikasikan ke tanaman kopi arabika yang berumur 8 tahun. Pupuk kompos diberikan dengan cara membuat piringan dan membenamkan kompos melingkari tanaman kopi pada kedalaman 10-15 cm. Lubang kompos dibuat dengan melihat kanopi kopi terpendek dari pangkal batang. Pupuk kompos diberikan dengan cara larikan di dalam piringan yang telah dibuat kemudian di aduk rata dengan tanah setelah dibenamkan, tanaman kopi yang diberi kompos dibiarkan selama 3 bulan dan dilakukan perawatan yaitu pengangkasan dan membersihkan gulma.

\section{Pengambilan Contoh Tanaman}

Pengambilan contoh tanaman dilakukan setelah tiga bulan pengaplikasian kompos ke tanah. Jaringan daun yang berada diposisi ke-3 sampai ke- 6 adalah posisi daun yang paling tepat dijadikan sampel. Sampel daun yang diambil berjumlah 16 helai daun. Sampel daun yang diambil yaitu daun yang berada pada ranting pada cabang primer (Pushparajah, 1994). Sampel daun kopi arabika yang telah diambil dimasukkan kedalam amplop yang terlebih dahulu dilubangi dan diberilabel. Daun yang diambil dikompositkan kemudian dianalisis dilaboratorium. Parameter daun tanaman yang diamati adalah kandungan hara Nitrogen, Fosfor dan Kalium. 


\section{HASILDAN PEMBAHASAN}

\section{Analisis Awal}

Hasil analisis awal kandungan Nitrogen, Fosfor, Kalium, Kalsium dan Magnesium dapat dilihat pada Tabel 1.

Tabel 1. Analisis Awal Sifat Kimia Tanah Andisol

\begin{tabular}{lll}
\hline Aspek Analisis & Rata-rata & Kriteria \\
\hline Nitrogen $(\%)$ & 0.20 & Rendah \\
Fosfor $\left(\mathrm{mg} \mathrm{kg}^{-1}\right)$ & 2.00 & Rendah \\
Kalium $\left(\mathrm{cmol} \mathrm{kg}^{-1}\right)$ & 0,30 & Sedang \\
Kalsium $\left(\mathrm{cmol} \mathrm{kg}^{-1}\right)$ & 3.48 & Rendah \\
Magnesium $\left(\mathrm{cmol} \mathrm{kg}^{-1}\right)$ & 0.42 & Rendah \\
\hline
\end{tabular}

Berdasarkan Tabel 1 dapat dilihat bahwa kandungan $\mathrm{N}$ memiliki kriteria rendah dengan nilai $0,20 \%$ nilai $\mathrm{N}$ yang rendah dikarenakan tanah Andisol didominasi oleh alofan yang dapat melindungi bahan organik sehingga bahan organik sulit terurai (Yuniarti et al., 2008). Kadungan $P$ memliliki kriteria rendah dengan nilai $2.00 \mathrm{mg} \mathrm{kg}^{-1}$, ketersediaan unsur hara P sangat rendah pada Andisol dikarenakan Andisol merupakantanah yang terbentuk dari bahan vulkanik yang mengandung beberapa mineral salah satunya mineral alofan yang dapat mengikat $\mathrm{P}$ sehingga $\mathrm{P}$ menjadi tidak tersedia (Hifnalisa et al., 2017). Kandungan K memiliki kriteria sedang dengan nilai $0,30 \mathrm{cmol} \mathrm{kg}{ }^{-1}$. Penggunaan bahan organik dapat menunjukkan dinamika kandungan $\mathrm{K}$ tanah yang selalu berubah setiap waktu dan pada jenis tanaman yang berbeda (Sudjatmiko et al., 2018).

\section{Kandungan Beberapa Hara Pada Berbagai Jenis Kompos}

Hasil analisis kompos yang telah dianalisis di Laboratorium Penelitian Tanah dan Tanaman Fakultas Pertanian disajikan pada Tabel 2.

Tabel 2. Hasil Analisis Kompos

\begin{tabular}{|c|c|c|c|c|c|c|}
\hline \multirow{2}{*}{$\begin{array}{l}\text { Komponen } \\
\text { Analisis }\end{array}$} & \multicolumn{2}{|c|}{ Perlakuan } & \multirow[b]{2}{*}{$\begin{array}{l}\text { Kulit } \\
\text { Biji } \\
\text { Kopi } \\
(\%) \\
\end{array}$} & \multirow[b]{2}{*}{$\begin{array}{l}\text { Tithonia } \\
\text { diversifolia } \\
\text { Lamtoro } \\
\qquad \%)\end{array}$} & \multirow[b]{2}{*}{$\begin{aligned} & \text { Tithonia } \\
&+ \text { diversifolia }+ \\
& \text { Limbah Kulit } \\
& \text { Biji Kopi }(\%) \\
&\end{aligned}$} & \multirow[b]{2}{*}{$\begin{array}{l}\text { Lamtoro + } \\
\text { Limbah Kulit } \\
\text { Biji Kopi }(\%)\end{array}$} \\
\hline & $\begin{array}{l}\text { Tithonia } \\
\text { diversifolia }(\%)\end{array}$ & $\begin{array}{l}\text { Lamtoro } \\
\%)\end{array}$ & & & & \\
\hline $\mathrm{N}$ & 1,60 & 2,25 & 0,16 & 2,05 & 1,13 & 1,60 \\
\hline $\mathrm{P}$ & 0,86 & 0,45 & 0,08 & 0,43 & 0,12 & 0,17 \\
\hline $\mathrm{K}$ & 1,81 & 1,49 & 0,90 & 1,83 & 1,57 & 1,41 \\
\hline $\mathrm{Ca}$ & 0,36 & 0,73 & 1,14 & 1,39 & 0,58 & 1,68 \\
\hline $\mathrm{Mg}$ & 0,92 & 0,99 & 0,66 & 0,82 & 0,42 & 0,64 \\
\hline
\end{tabular}

Sumber: Hifnalisa et al., 2020

Kandungan Nitrogen dari keenam jenis pupuk memiliki nilai berkisar 1,13\%-2,25\%, nilai tertinggi terdapat pada kompos lamtoro dan terendah terdapat pada kompos T.diversifolia+limbah biji kopi. Kandungan $\mathrm{N}$ pada keenam jenis kompos tersebut sudah memenuhi standar SNI yaitu 0,40 \% dengan demikian semua jenis kompos yang dijadikan perlakuan mengandung hara $\mathrm{N}$ yang cukup (SNI, 2004) dan sudah memenuhi standar minimal 
dari Keputusan Menteri Pertanian. Standar minimal pupuk organik padat/komposminimal 2\% yaitu kandungan N+P+K (KEMENTAN, 2019).

Kompos dapat menyediakan media tanam yang dapat digunakan untuk membentuk jaringan pertumbuhan tanaman dengan komponen asam amino dan protein, termasuk auksin. Auksin berperan dalam merangsang pertumbuhan akar dan jaringan, sehingga akar sangat efektif dalam penyerapan unsur hara makro dan mikro (Yuwono, 2006).

Kandungan Fosfor berdasarkan Tabel 2 menunjukkan bahwa dari keenam jenis pupuk memiliki nilai berkisar 0,08 \% - 0,86\%. Nilai tertinggi terdapat pada kompos $T$. diversifolia dan nilai terendah terdapat pada kompos limbah kulit kopi. Kandungan $\mathrm{P}$ pada keenam jenis kompos tersebut sudah memenuhi standar SNI yaitu 0,10\% hanya kompos limbah biji kopi saja yang tidak memenuhi standar SNI walaupun limbah biji kopi tidak memenuhi standar SNI tetapi sudah memenuhi standar minimal kandungan $\mathrm{N}+\mathrm{K}+\mathrm{P}$ pupuk organik. Jenis kompos lainnya yang dijadikan perlakuan mengandung hara P yang cukup (SNI, 2004). Hasil analisis pupuk kompos sudah memenuhi standar minimal pupuk organik padat/kompos minimal $2 \%$ kandungan $\mathrm{N}+\mathrm{P}+\mathrm{K}$ (KEMENTAN, 2019).

Unsur hara fosfor disebabkan karena adanya pelapukan bahan organik yang berasal dari sisa tanaman yang dijadikan kompos. Fosfor sebagian besar berasal dari pelapukan batuan mineral alam, sisanya berasal dari pelapukan bahan organik, dan bahan organik berasal dari sisa tanaman yang dijadikan kompos. Sumber fosfor banyak terdapat didalam tanah, tetapi tumbuhan masih mengalami kekurangan fosfor. Kebanyakan senyawa fosfor sulit larut dalam air karena fosfor terikat secara kimiawi oleh unsur lain (Novizan, 2004).

Kandungan Kalium berdasarkan Tabel 2 menunjukkanbahwa dari keenam jenis pupuk memiliki nilai berkisar $0,90 \%-1,83 \%$, nilai tertinggi terdapat padakompos $T$. diversifolia+lamtoro dan terendah terdapat pada kompos limbah biji kopi, kandungan Kpada keenam jenis kompos tersebut sudah memenuhi standar SNI yaitu 0,20\% dengan demikian semua jenis kompos yang dijadikan perlakuan mengandung hara K yang cukup (SNI, 2004). Hasil analisis pupuk kompos sudah memenuhi standar minimal pupuk organik padat/kompos minimal $2 \%$ kandungan $\mathrm{N}+\mathrm{P}+\mathrm{K}$ (KEMENTAN, 2019).

Unsur hara kalium didalam pupuk kompos berasal dari bahan organik. Kalium adalah unsur hara esensial untuk pertumbuhan dan perkembangan biologi tanaman. Tanaman membutuhkan kalium dari larutan tanah sebagai ion $\mathrm{K}+$ yang konsentrasinya dalam larutan sangat rendah. Kaliumdigunakan sebagai katalisator oleh mikroorganisme di dalam substrat. Kehadiran mikroorganisme akan sangat mempengaruhi peningkatan kalium (Hardianiet al., 2011).

\section{Kandungan Nitrogen (N) pada Daun Tanaman Kopi Arabika}

Hasil analisis di laboratorium menunjukan bahwa pemberian beberapa pupuk kompos sangat berpengaruh nyata terhadap kandungan Nitrogen di tanaman kopi arabika. Rata-rata nilai kandungan $\mathrm{N}$ akibat beberapa perlakuan pemberian kompos dapat dilihat pada Tabel 3 .

Tabel 3 menunjukan bahwa penggunaan kompos sangat berbeda nyata dengan tanpa kompos terhadap kandungan $\mathrm{N}$ pada daun kopi arabika. Pemberian kompos dapat meningkatkan kandungan $\mathrm{N}$ daun kopi. Pemberian kompos T.diversifolia dan kulit biji kopi tidak berbeda nyata dengan control sedangkan pemberian kompos lamtoro, $T$. diversifolia+lamtoro, $T$. diversifolia+kulit biji kopi dan lamtoro+kulit biji kopi sangatberbeda nyata dengan kontrol namun semua jenis kompos yang digunakan tidak berbeda nyata terhadap pemberian $\mathrm{N}$ pada tanaman kopi arabika. Kandungan $\mathrm{N}$ tertinggi daun kopi arabika pada penggunaan kompos lamtoro memiliki nilai sebesar 2,93\% yang sangat berbeda nyata dengan kontrol tetapi tidak berbeda nyata dengan semua perlakuan. Kandungan $\mathrm{N}$ daun kopi 
arabika memiliki kadar $\mathrm{N}$ berkisar 1,87\% - 2,93 \%. Kandungan $\mathrm{N}$ yang memiliki kriteria rendah memiliki nilai berkisar 1,60 - 2,49\% dan yang memiliki kriteria cukup memiliki nilai berkisar 2,50 - 3,50 \% pada daun tanaman kopi (Jones et al., 1991).

Tabel 3. Rata-Rata Kandungan N pada Daun Tanaman Kopi Arabika

\begin{tabular}{lll}
\hline Perlakuan ( Jenis Kompos) & Rata-rata (\%) & Kriteria \\
\hline Tanpa Kompos & $1,87 \mathrm{a}$ & Rendah \\
Tithoniadiversifolia & $2,23 \mathrm{ab}$ & Rendah \\
Lamtoro & $2,93 \mathrm{~b}$ & Cukup \\
Kulit Biji Kopi & $2,26 \mathrm{ab}$ & Rendah \\
Tithonia diversifolia + Lamtoro & $2,56 \mathrm{~b}$ & Cukup \\
Tithonia diversifolia + Kulit BijiKopi & $2,89 \mathrm{~b}$ & Cukup \\
Lamtoro + Kulit Biji Kopi & $2,34 \mathrm{~b}$ & Rendah \\
\hline $\mathrm{BNJ}_{0.01}$ & 0,67 & \\
\hline
\end{tabular}

Pemberian kompos dapat meningkatkan kandungan $\mathrm{N}$ pada tanaman kopi arabika disebabkan karena keenam jenis pupuk kompos memiliki nilai kandungan $\mathrm{N}$ yang tinggi. Pupuk kompos lamtoro dapat meningkatkat perkembangan mikroorganisme, menyediakan unsur hara makro dan mikro dan menjaga kesuburan tanah. Pupuk kompos daun lamtoro memiliki ketersediaan hara $\mathrm{N}$ yang tinggi dan unsur hara $\mathrm{N}$ tersebut dibutuhkan pada saat pertumbuhan tanaman, terutama pada pertumbuhan daun tanaman. Kandungan $\mathrm{N}$ dapat meningkatkan jumlahnyadidalam tanah akibat pemberian pupuk kompos. Kandungan Nitrogen tanah meningkatkan dari $0.24 \%$ menjadi $0.25 \%$ akibat pemberian kompos (Yuniarti et al., 2008).

\section{Kandungan Fosfor (P) pada Daun Tanaman Kopi Arabika}

Hasil analisis di laboratorium menunjukkan bahwa pemberian beberapa pupuk kompos sangat berpengaruhnyata terhadap kandungan Fosfor ditanaman kopi arabika. Ratarata nilai kandungan $\mathrm{P}$ akibat beberapa perlakuan pemberian kompos dapat dilihat pada Tabel 4.

Tabel 4. Rata-Rata Kandungan P pada Daun Tanaman Kopi Arabika

\begin{tabular}{lll}
\hline Perlakuan (Jenis Kompos) & Rata-rata(\%) & Kriteria \\
\hline Tanpa Kompos & $0,34 \mathrm{a}$ & Cukup \\
T.diversifolia & $0,49 \mathrm{ab}$ & Tinggi \\
Lamtoro & $0,52 \mathrm{ab}$ & Tinggi \\
Kulit Biji Kopi & $0,62 \mathrm{~b}$ & Tinggi \\
T. diversifolia + Lamtoro & $0,49 \mathrm{ab}$ & Tinggi \\
T. diversifolia + Kulit BijiKopi & $0,45 \mathrm{ab}$ & Tinggi \\
Lamtoro + Kulit Biji Kopi & $0,53 \mathrm{~b}$ & Tinggi \\
\hline BNJ $_{0.01}$ & 0,18 & \\
\hline
\end{tabular}

Tabel 4 menunjukan bahwa penggunaan kompos sangat berbeda nyata dengan tanpa kompos terhadap kandungan $\mathrm{P}$ pada daun kopi arabika. Pemberian kompos dapat 
meningkatkan kandungan $\mathrm{P}$ pada daun kopi arabika. Pemberian kompos T.diversifolia, lamtoro, $T$. diversifolia+lamtoro dan $T$. diversifolia + kulit biji kopi tidak berbeda nyatadengan tanpa kompos. Pemberian kompos kulit biji kopi dan lamtoro+kulit biji kopi sangat berbeda nyata dengan tanpa kompos namun semua jenis kompos yang digunakkan tidak berbeda nyata terhadap peningkatan $\mathrm{P}$ pada tanaman kopi arabika. Kandungan $\mathrm{P}$ tertinggi daun kopi arabika dijumpai pada penggunaan kompos lamtoro memiliki nilai sebesar $0,62 \%$ yang berbeda nya dengan kontrol tetapi tidak berbeda nyata dengan perlakuan lainnya. Kandungan $\mathrm{P}$ daun kopi arabika memiliki kadar $\mathrm{P}$ berkisar 0,34\% - 0,62 \%. Kandungan $\mathrm{P}$ yang memiliki kriteria cukup memiliki nilai berkisar $0,15-0,35 \%$ dan yang memiliki kriteria tinggi memiliki nilai berkisar $>0,35 \%$ pada daun tanaman kopi \%. (Jones et al., 1991).

Berdasarkan hasil analisis kompos dapat dilihat pada Tabel 2 bahwa nilai $\mathrm{P}$ tertinggi terdapat pada kompos T.diversifolia yaitu sebesar $0,86 \%$ dan dari analisis tanaman di lihat bahwa nilai P tertinggi pada perlakuan kulit biji kopi yaitu sebesar $0,62 \%$, hal ini di berbeda dengan analisis kompos. Nilai analisis kompos menunjukan kandungan $\mathrm{P}$ rendah yaitu sebesar 0,08\% dan tidak mampu menambahkah unsur hara $\mathrm{K}$ tetapi pemberian kompos limbah biji kopi dapat mengaktipkan mikroorganisme tanah dalam melepaskan hara $\mathrm{P}$ sehingga tersedia bagi tanaman. T. diversifolia sangat mudah untuk temukan di sekitar perkebunan kopi, ditemukan pada pengolahan kopi di Kabupaten Bener Meriah. (Hifnalisa et al., 2018).

Kulit biji kopi bisa bertambah P-tersedia dalam tanah sehingga kebutuhan $\mathrm{P}$ oleh tanaman terpenuhi. Aplikasi biji kopi di Andisol yang dihasilkan ketersediaan $\mathrm{P}$ tanah dan kandungan $\mathrm{P}$ yang lebih tinggi pada daun kopi dibandingkan dengan aplikasi T.diversifolia (Hifnalisa et al., 2018). Penambahan bahan organik kompos kulit kopi di dalam tanah akan meningkatkan populasi mikroorganisme di dalam tanah, sehingga dapat penambahan bahan organik kompos kulit kopi dalam tanah akan menyebabkan populasi dan mikrooganisme dalam tanah meningkat, sehingga menyebabkan pelepasan unsur hara yang belum terurai dalam medium tanah dapat dipercepat (Atmojo, 2003).

\section{Kandungan Kalium (K) padaDaun Tanaman Kopi Arabika}

Hasil analisis di laboratorium menunjukan bahwa pemberian beberapa pupuk kompos berpengaruhnyata terhadap kandungan $\mathrm{K}$ ditanaman kopi arabika. Rata-rata nilai kandungan $\mathrm{K}$ akibat beberapa perlakuan pemberian kompos dapat dilihat pada Tabel 5.

Tabel 5. Rata-Rata Kandungan K pada Daun Tanaman Kopi Arabika

\begin{tabular}{lll}
\hline Perlakuan(Jenis Kompos) & Rata-rata (\%) & Kriteria \\
\hline Tanpa Kompos & $0,99 \mathrm{a}$ & Rendah \\
Tithoniadiversifolia & $1,25 \mathrm{~b}$ & Rendah \\
Lamtoro & $1,21 \mathrm{ab}$ & Rendah \\
Kulit Biji Kopi & $1,25 \mathrm{~b}$ & Rendah \\
Tithonia diversifolia + Lamtoro & $1,29 \mathrm{~b}$ & Rendah \\
Tithonia diversifolia + Kulit Biji Kopi & $1,15 \mathrm{ab}$ & Rendah \\
Lamtoro + Kulit Biji Kopi & $1,24 \mathrm{ab}$ & Rendah \\
\hline BNJ $_{0.05}$ & 0,23 &
\end{tabular}

Tabel 5 menunjukan bahwa penggunaan kompos berbeda nyata dengan tanpa kompos terhadap kandungan $\mathrm{K}$ total pada daun kopi arabika. Pemberian kompos dapat meningkatkan 
kandungan $\mathrm{K}$ daun kopi. Pemberian lamtoro, $T$. diversifolia+kulit biji kopi dan lamtoro+kulit biji kopi tidak berbeda nyata dengan tanpa kompos dan pemberian kompos T.diversifolia, kulit biji kopi dan lamtoro+kulit biji kopi berbeda nyata dengan tanpa kompos namun semua jenis kompos yang digunakan tidak berbeda nyata terhadap peningkatan $\mathrm{K}$ pada tanaman kopi arabika. Kandungan $\mathrm{K}$ tertinggi daun kopi arabika dijumpai pada penggunaan kompos $T$. diversifolia+lamtoro memiliki nilai sebesar $1,29 \%$ yang berbeda nyata dengan tanpa kompos tetapi tidak berbeda nyata dengan perlakuan lainnya. Kandungan $\mathrm{K}$ memiliki kriteria rendah memiliki nilai berkisar (1,50 -1,99 \%) pada daun tanaman kopi (Jones et al., 1991).

Pemberian kompos dapat meningkatkan kandungan $\mathrm{K}$ pada daun kopi arabika diduga akibat pengaruh pemberian beberapa jenis kompos. Pupuk kompos T. diversifolia+lamtoro memiliki ketersediaan hara $\mathrm{K}$ yang tinggi dan unsur hara $\mathrm{K}$ tersebut dibutuhkan pada saat pertumbuhan tanaman, terutama pada pertumbuhan daun tanaman. Pemberian pupuk kompos dapat membantu peningkatan kesuburan tanah dan dapat melepaskan unsur kalium dari mineral tanah sehingga kalium tersedia bagi tanaman. (Hardjowigeno, 2007).

\section{KESIMPULAN}

Pemberian pupuk kompos T. diversifolia, kompos lamtoro, kompos limbah kulit biji kopi, kompos T.diversifolia+lamtoro, kompos T. diversifolia+limbah kulit biji kopi, kompos lamtoro+limbah kulit biji kopi dengan dosis $12,5 \mathrm{~kg}$ pohon ${ }^{-1}$ dapat meningkatkan kandungan hara nitrogen, posfor, dan kalium pada tanaman kopi arabika. Kandungan hara Fosfor meningkat dari kriteria sedang menjadi tinggi akibat pemberian beberapa jenis kompos Sedangkan kandungan hara kalium memiliki kriteria rendah tanpa pemberian beberapa jenis kompos. Pemberian pupuk kompos T. diversifolia, kompos lamtoro, kompos limbah kulit biji kopi, kompos T.diversifolia+lamtoro, kompos T. diversifolia+limbah kulit biji kopi, kompos lamtoro+limbah kulit biji kopi dapat meningkatkan kandungan fosfor pada tanaman kopi arabika.

\section{DAFTAR PUSTAKA}

Atmojo. 2003. Peranan Bahan Organik terhadap Kesuburan Tanah dan Upaya Pengelolaannya. Universitas Sebelas Maret Press. Surakarta.

Badan Standarisasi Nasional (BSN). SNI 19-7030-2004. Spesifikasi Kompos dari Sampah Organik Domestik. Jakarta.

Dinas Perkebunan Provinsi Aceh. 2013. Prospek pengembangan kopi arabika gayo di Kabupaten Aceh Tengah dan Bener Meriah. Disbun. Aceh.

Falahuddin, I., Anita R.P.R dan Lekat H. 2016. Pengaruh pupuk organik limbah kulit kopi (Coffea Arabica) terhadap pertumbuhan bibit kopi. Jurnal Bioilmi. 2 : 108-118.

Hardiani, H., Teddy, K., dan Susi, S., 2011. Bioremedasi logam timbal (pb) dalam tanah terkontaminasi limbah studge industri kertas proses deinking. Jurnal Selulosa. 1: 31-41.

Hardjowigeno, S. 1993. Klasifikasi Tanah dan Pedogenesis. Akademika Pressindo. Jakarta.

Hardjowigeno, S. 2007. Ilmu Tanah. Akademika Pressindo. Jakarta.

Hifnalisa., Asmarlaili, S., T. Sabrina dan T. C. Nisa. 2017. P status in andisol and P content in arabica coffee seedling leaves due to the application of phosphate providing microorganisms and organic matters in BenerMeriah district. International Journal of Scientific and Technology Research. $6: 59-63$.

Hifnalisa, , Sahar, A., Sabrina, T. and Nisa, T.C. 2018. The application of microorganisms of phosphate providers and organic matters to improve the growth of Arabica coffee 
seedlings at Andisol in Bener Meriah Regency. World Journal of Engineering. 422428.

Hifnalisa., Y. Jufri dan Manfarizah. 2020. Pemanfaatan Bahan Organik Insitu Untuk Meningkatkan Kandungan Hara Tanah Andisol dan Tanaman Kopi Arabika yang dikelola Secara Organik di Kabupaten Bener Meriah. Fakultas Pertanian Universitas Syiah Kuala. Banda Aceh.

Jones, JB., Wolf, B and Mills, HA. 1991. Plant analysis hand book. Mikro-macro publishing, Inc.

Kementerian Pertanian. 2019. Standar Minimal Pupuk Organik. http://www.pertanian.go.id Diakses 28 Oktober 2020.

Novizan. 2004. Petunjuk Pemupukan Yang Efektif. Agromedia Pustaka. Jakarta.

Pushparajah, W. 1994. Leaf analysis and soil testing for plantation tree crops, international board for soil researchand management (ibsram) bangkok. Thailand.

Sudjamiko, S., Muktamar, Z., Chozin, M., Setyowati, N. dan Fahrurozi, F. 2017. Changes in chemical properties of soil in an organic agriculture syistem. Universitas of Bengkulu. Bengkulu.

Sukarma, D. A. 2014. Tanah andosol di Indonesia, karakteristik potensi, kendala dan pengelolaanya untuk pertanian. Balai Besar Penelitian Dan Pengembangan Sumberdaya Lahan Pertanian. Bogor. Hal: 144.

Yuniarti, Anni., M. Damayani dan D. M. Nur. The effect of organic and N, P, K fertilizers on organic C, total N, C/N, N uptake, and yields od black rice on Inceptisols. 2008. Jurnal Pertanian Presisi. Hal: 90-105.

Yuniarti, Anni., M. Damayani dan D. M. Nur. The effect of organic and N, P, K fertilizers on organic C, total N, C/N, N uptake, and yields od black rice on Inceptisols. 2008. Jurnal Pertanian Presisi. Hal: 90-105.

Yuwono, D. 2006. Kompos. Penebar Swadaya. Jakarta. 